\title{
To Apply or to Declare, or Both? Links between the Two Types of Intervention under the ICJ Statute
}

\section{Hyun Seok Park ${ }^{*}$}

It is conceivable that the construction of a convention is in question in a case brought before ICJ and a State that is a party to the convention but not to the case has legal interests which may be affected by the construction given by the judgment in the case. As hinted at in the Whaling in the Antarctic case and the Sovereignty over Pulau Ligitan and Pulau Sipadan case, such a third State might intervene in the proceedings under Article 62 as well as Article 63 of the Statute unless it should be interpreted otherwise. In light of relevant provisions of the Statute and jurisprudence of the Court, this paper explores the question whether such a State has the choice, to submit an application to intervene under Article 62 or to make a declaration of intervention under Article 63.

\section{Keywords}

Intervention as of Right, Discretionary Intervention, Non-Party Intervener, Intervener as a Party, IC J Statute, Article 62, Article 63

* Professor of International Law at Hongik University, Seoul, Korea. LL.B./LL.M./Ph.D.(SNU). The author may be contacted at: ctrl_83@hanmail.net / Address: 94 Wausan-ro, Mapo-gu, Seoul 121-791 Korea. 


\section{Introduction}

The Statute of the International Court of Justice (hereinafter ICJ Statute) provides two different forms of intervention for a third State who is willing to protect its own interest in a case already brought before the Court. If a third State considers that it has a legal interest which may be affected by the decision of the Court in the case, the State is allowed to submit a request to the Court for permission to intervene in accordance with Article 62 of the ICJ Statute. If a multilateral treaty is in question regarding its interpretation before the Court, Article 63 grants a third State who is a party to the treaty the right to intervene in the proceedings.

In the Whaling in the Antarctic case, Japan has argued that New Zealand's declaration of intervention under Article 63 of the ICJ Statute can be interpreted as a strategy to avoid the burden of proving an "interest of a legal nature which may be affected by the decision in the case," as required under Article 62. 'By contrast, the Philippines has invoked Article 62 instead of Article 63 to intervene in the Sovereignty over Pulau Ligitan and Pulau Sipadan case. It considered having an interest of a legal nature which might be affected by the Court's interpretation of certain treaties to which it is the successor-in-interest of one party. ${ }^{2}$

In the S. S. Wimbledon case, Poland also filed an application for permission to intervene into the interpretation of the Treaty of Peace of Versailles, to which Poland was then also a party, under Article 62 of the Statute of the Permanent Court of International Justice (hereinafter PCIJ Statute). ${ }^{3}$ From a further communications with PCIJ, it appears to the Court that: "The Polish Government, abandoning the exclusive course which it seemed in the first instance to have adopted, now intends to avail itself of the right conferred upon it, as a party to the Treaty of Versailles, by Article 63 of the Statute." Poland did not insist that the grounds for justifying the intervention under Article 62 should be taken into consideration. ${ }^{5}$ PCIJ determined

1 ICJ, Written Observations of Japan on New Zealand's Written Observations (hereinafter Written Observations of Japan), ๆף 1-4, re-cited from Whaling in the Antarctic (Austl. v. Japan), Order, 2013 I.C.J. (Feb. 6) (Separate Opinion of Judge Cançado Trindade), available at http://www.icj-cij.org/docket/files/148/17272.pdf (last visited on Oct. 18, 2013). For an account of this dispute, see R. Davis, The Whaling Dispute in the South Pacific: an Australian Perspective, 4 J. EAST Asia \& InT'L L. 419 (2012).

2 See Sovereignty over Pulau Ligitan and Pulau Sipadan (Indon. v. Malay.), Judgment, 2001 I.C.J. 580 (Oct. 23). The Application was rejected.

3 See Application by Polish Government to Intervene of May 22, 1923, S.S. Wimbledon (U.K., France, Italy, Japan $v$. Germ.), 1923 P.C.I.J. (ser. A) No.1, at 9-10.

4 See S.S. Wimbledon (U.K., France, Italy, Japan v. Germ.), 1923 P.C.I.J. (ser. A) No.1, at 13 (Jun. 28).

5 Id. 
the question on the basis of Article 63. ${ }^{6}$ It seems unclear, however, whether the Court could have regarded the request to intervene under Article 62 as a declaration of intervention under Article 63 if Poland had insisted on taking the same course as her original one. The Court itself appears to have left this question open by saying: "The attitude thus adopted renders it unnecessary for the Court to consider and satisfy itself whether Poland's intervention in the suit before it is justified by an interest of a legal nature, within the meaning of Article 62 of the Statute."7 In this connection, a question may arise whether a third State party to a convention should be permitted to intervene in a case where the construction of the convention was in question if the State submitted a request to that effect under Article 62 without invoking Article 63.

The primary objective of this research is to find a new answer to such an old question. In view of the so-called 'resurrection' of intervention in recent cases before ICJ, the question seems to have more practical importance than before. This paper is composed of five parts including Introduction and Conclusion. Part two will make a distinction between the two forms of intervention under the relevant provisions of the Statute. One is the so-called "discretionary intervention" under Article 62 of the ICJ Statute, and the other is the "intervention as of right" ${ }^{\text {" }}$ under Article 63. Part three will analyze legal interests of a third State in the interpretation of a multilateral treaty to which it is also a party in light of the requirements for intervention under Article 62 of the Statute. Under Article 62, a would-be intervener should prove that: (1) "it has an interest of a legal nature"; and (2) "which may be affected by the decision in the case." Part four will review the effects of judgments on intervening States. The author will review those effects on an intervener as a party and on a nonparty intervener consecutively.

\section{Differences between the Two Forms of Intervention}

\section{A. Discretionary Intervention}

The concept of 'discretionary intervention' first appeared in the draft plans for

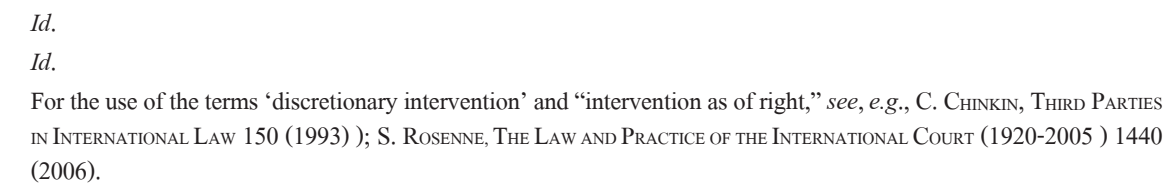
in International Law 150 (1993) ); S. Rosenne, The Law and Practice of the International Court (1920-2005) 1440 (2006). 
PCIJ proposed by some States. ${ }^{9}$ It is different from the procedure of "intervention as of right" under Article 63 of the ICJ Statute in the sense that the Court has some discretion under Article 62 whether or not to grant a third State permission to intervene, while a would-be intervener under Article 63 does not need to seek permission to intervene from the Court. The discretionary intervention was introduced into the draft PCIJ Statute by the Advisory Committee of Jurists during their discussion of the "intervention as of right." On the question of discretionary intervention, the Advisory Committee reported as follows:

\begin{abstract}
There are three possibilities: a party may wish to take sides with the plaintiff or the defendant; a party may claim certain exclusive rights; or a party may request that one of the two contesting States should withdraw on the ground that it is not the real dominus of the right which it claims. In this latter case intervention tends to become exclusion, but as a rule a State is content to take joint action with one of the parties: should this be allowed? The Committee replies in the affirmative, but on condition that an interest of a legal nature [un intérêt d'ordre juridique] is involved. The Court is to decide whether the interest is legitimate and consequently whether the intervention is admissible. To refuse all right of intervention, [sic] might have unfortunate results. The essential point is to limit it to cases in which an interest of a legal nature can be shown, so that political intervention will be excluded, and to give the Court the right of decision. ${ }^{10}$
\end{abstract}

The draft text of Article 62 of the PCIJ Statute for discretionary intervention is substantially identical with that of the ICJ Statute. The ICJ Statute just deleted the phrase "as a third party" after "to be permitted to intervene" in the English text of Article 62. It is the only change that the Washington Committee of Jurists for drafting the new Statute made. In the French text, however, the wording of Article 62 remains unchanged in the present Statute because there was no corresponding expression in the French text of the PCIJ Statute. ${ }^{11}$ The Washington Committee of Jurists deleted the phrase, but did not intend that there should be any change in the meaning of the provision. ${ }^{12}$ No other comments or proposals regarding Article 62 were submitted

9 C. Chinkin, Article 62, in The Statute of the International Court of Justice: A Commentary 1532 (A. Zimmermann et al eds., 2012).

10 PCIJ Advisory Committee of Jurists, Procès-Verbaux of the Proceedings of the Committee: June 16 - July 24, 745-746

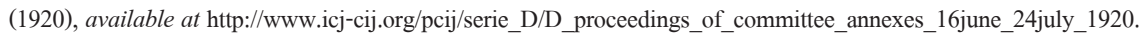
pdf (last visited on Oct. 28, 2013). See also Continental Shelf (Tunis. v. Libya), Judgment, 1981 I.C.J. $12-14$ (Apr. 14).

11 Article 62 in the French text of the ICJ Statute stipulates: (1) Lorsqu'un État estime que, dans un différend, un intérêt d'ordre juridique est pour lui en cause, il peut addresser à la Cour une requête, à fin d'intervention. (2) La Cour décide.

12 Report on the Draft Statute of the International Court of Justice referred to in Chapter VII of the Dumbarton Oaks 
to the Washington Committee of Jurists or to the San Francisco Conference in $1945 .{ }^{13}$ Article 62 of the ICJ Statute was finally adopted in its current form as follows:

1. Should a State consider that it has an interest of a legal nature which may be affected by the decision in the case, it may submit a request to the Court to be permitted to intervene.

2. It shall be for the Court to decide upon this request.

So far, fifteen applications have been submitted for permission to intervene under Article 62 before ICJ; only three of them were successful. ${ }^{14}$ The decision to grant or refuse an application mainly depends upon what kind of legal interest the State has. ${ }^{15}$ In practice, a State submitting an application must prove its legal interest in order that the Court regards it as sufficient to justify intervention. In its decision on the question of intervention by Poland, PCIJ has stated: ${ }^{16}$

The first of these forms of intervention is that dealt with in Article 62 of the Statute and Articles 58 and 59 of the Rules of Court; it is based on an interest of a legal nature advanced by the intervening party and the Court should only admit such intervention if, in its opinion, the existence of this interest is sufficiently demonstrated.

A crucial issue in this respect is what is required under Article 62 to show "an interest of a legal nature" in this context. It still remains unclear; ${ }^{17}$ we may make some inferences from the drafting history of this provision and the jurisprudence of the Court, as will be discussed below.

Another key expression, "which may be affected by the decision in the case," would raise some questions whether the intervener shall be bound by the decision in the case and, if so, to what extent. ${ }^{18}$ To answer these questions may seemingly

Proposals (Jules Badesvant, Rapporteur), 14 UNCIO 849, re-cited from S. ROSENNE, INTERVENTION IN THE INTERNATIONAL Court of Justice 31 (1993).

13 Rosenne, supra note 8, at 1445.

14 For details, see supra note 9, at 1535.

15 B. Bonafé, Interests of a Legal Nature Justifying Intervention before the ICJ, 25 LEIDEN J. INT'L L. 739-740 (2012).

16 Supra note 4, at 12.

17 See, e.g., supra note 15, at 740; P. Palchetti, Opening the International Court of Justice to Third States: Intervention and Beyond, 6 Max Planck U.N.Y.B. 142 (2002); Rosenne, supra note 12, at 196.

$18 C f$. This question is expressly dealt with in Article 31 of the ITLOS Statute, which reads as follows:

1. Should a State Party consider that it has an interest of a legal nature which may be affected by the decision in any dispute, it may submit a request to the Tribunal to be permitted to intervene.

2. It shall be for the Tribunal to decide upon this request.

3. If a request to intervene is granted, the decision of the Tribunal in respect of the dispute shall be binding upon the intervening State Party in so far as it relates to matters in respect of which that State Party intervened. [Emphasis added]. 
depend upon whether the third State is a party to the case or not, since Article 59 of the ICJ Statute provides that: "The decision of the Court has no binding force except between the parties and in respect of that particular case." In that regard, it has been controversial whether some jurisdictional link has to exist between a State seeking to intervene under Article 62, and either or both of the principal parties to the case. ${ }^{19}$ In cases of intervention under Article 63, conversely, the Court's construction of the convention will be equally binding upon the intervening State even if it is just a nonparty intervener.

\section{B. Intervention as of Right}

Whereas the 'discretionary intervention' was created by Article 62 of the PCIJ Statute, the "intervention as of right" had its origins in existing provisions relating to international arbitration including Article 16 of the Draft Regulation for International Arbitral Procedure adopted by L'Institut de Droit International in 1875 and Article 56 of the Convention for the Pacific Settlement of International Disputes adopted in the 1899 Hague Peace Conference. ${ }^{20}$ The revised version of the latter was Article 84 of the same Convention adopted in the Second Hague Peace Conference held in 1907, which directly inspired Article 63 of the PCIJ Statute. ${ }^{21}$ Immediately after the paragraph on discretionary intervention quoted above, the Report of the Advisory Committee of Jurists states:

Further there is one case in which the Court cannot refuse a request to be allowed to intervene; that is in questions concerning the interpretation of a Convention in which States, other than the contesting parties, have taken part; each of these is to have the right to intervene in the case. If such a State uses this right, the interpretation contained in the sentence becomes binding between it and the other parties to the case.

Where collective treaties are concerned, general interpretations can thus be obtained very quickly, which harmonise with the character of the Convention. ${ }^{22}$

The Washington Committee of Jurists did not discuss further and adopted Article 63 of the ICJ Statute without change. This Article finally reads as follows:

19 Rosenne, supra note 12, at 32. See also M. Nordquist et al., United Nations Convention on the Law of the Sea 1982 (V) 392-393 (1989).

20 Supra note 9, at 1575-77. See also Rosenne, supra note 12, at 2.

21 Rosenne, supra note 12, at 23.

22 PCIJ Advisory Committee of Jurists, supra note 10, at 746: 
1. Whenever the construction of a convention to which States other than those concerned in the case are parties is in question, the Registrar shall notify all such States forthwith.

2. Every State so notified has the right to intervene in the proceedings; but if it uses this right, the construction given by the judgment will be equally binding upon it.

Whereas Article 62 gives ICJ some discretion whether or not to grant a third State permission to intervene, Article 63 is formulated in terms of a right to intervene, i.e., a third State party to the convention in question does not need to seek permission to intervene from the Court. Under Article 63, it is not necessary for a wouldbe intervener to prove an interest of a legal nature which may be affected by the decision in the case, save that it is a party to the convention whose interpretation is in question in the case. ${ }^{23}$ Although Article 63 offers States parties to a multilateral treaty a seemingly wide opportunity to intervene, it has rarely been used. ${ }^{24}$

Judge Gaja has asserted that States are generally reluctant to invoke this right mainly because the intervener should be bound by the interpretation of the Court in accordance with Article 63, paragraph $2 .^{25}$ Judge Oda Shigeru has noted: "There will not be much difference between those States which have intervened in a case and those States which have not intervened, so far as the practical effect of the Court's construction of an international convention is concerned"26 Although the Court's decision would influence the interpretation of the treaty in question for all States parties, it is not formally binding on any State that is neither a party to the case nor an intervener in the proceedings. States potentially interested in submitting observations seem to hesitate to do so because it would formally bound by the interpretation of the Court.

Considering such general reluctance, only the State having a real interest in the interpretation of the convention will invoke her right of intervention under Article 63. Judge Hudson noted: "The fact that a State is a party to a convention to be construed may be regarded as establishing that State's legal interest so that

23 Supra note 9, at 1575.

24 For the list of cases in which this right of intervention has been used up to 2012, see Id, at 1578. In 2013, New Zealand made a successful declaration of intervention in the Whaling in the Antarctic case. See Whaling in the Antarctic (Austl. v Japan), Oder, 2013 I.C.J. (Feb. 6), available at http://www.icj-cij.org/docket/files/148/17268.pdf (last visited on Oct. 28, 2013).

25 G. Gaja, A New Way for Submitting Observations on the Construction of Multilateral Treaties to the International Court of Justice, in From Bilateralism to Communty Interests: Essays in Honour of Judge Bruno Simma 699 (U.Fastenrath et al. eds., 2011).

26 S. Oda, Intervention in the International Court of Justice: Articles 62 and 63 of the Statute, in VöLKERRECHT ALS Rechtsordnung, Internationale Gerichtsbarkeit, Menschenrechte: Festschrift für Hermann 646 (1983). 
a judgment of the Court will not ordinarily be required." ${ }^{27}$ Professor Rosenne has also asserted: "Hints were given during the drafting of the Statute in 1920, that intervention under Article 63 is a form of intervention to protect an interest of a legal nature, not which may be affected by the decision in the case but in a more limited sense that it may be affected by the interpretation given by the Court to the multilateral treaty in question." 28

Article 63 provides the only requirement for the third party's intervention, "the construction of a convention to which States other than those concerned in the case are parties is in question." However, ICJ has stated in the Haya de la Torre case that "every intervention is incidental to the proceedings in a case" and accordingly "a declaration filed as an intervention only acquires that character in law if it actually relates to the subject-matter of the pending proceedings." ${ }^{29}$ Thus, Article 63 seems to require that the interpretation of a provision in the convention should be disputed between the parties to the case. ${ }^{30}$ Even in this case, however, a third State party to the convention cannot intervene into the interpretation of another provision of the convention which has nothing to do with each other. ${ }^{31}$

27 M. Hudson, The Permanent Court of International Justice: A Treatise 422 (1934), re-cited from Chinkin, supra note 9, at 1577, who adds: "Although the procedure contained in Art. 63 has the longer history, Hudson suggested that Art. 63 can be regarded as a special instance of the general principle laid down in Art. 62."

28 Rosenne, supra note 12, at 73. See also D. Greig, Third Party Rights and Intervention before the International Court, 32 VA. J. INT'L L. 285 (1991-1992). Professor Greig states: “Article 63 of the Statute can be interpreted as a specific instance of article 62 . The fact that the third state is a party to a convention which is in issue in the proceedings is, by article 63 , in effect deemed to constitute an interest of a legal nature and thus give rise to a right of intervention."

29 Haya de la Torre, 1951 I.C.J. 71, 76 (Jun. 13). In this case, Cuba made a declaration of intervention under Article 63. When El Salvador made a declaration of intervention in the Nicaragua case, the Court determined that El Salvador had not shown the intervention to relate to the subject-matter of the pending proceedings. See Military and Paramilitary Activities in and against Nicaragua (Nicar. v. U.S.), 1984 I.C.J. 215, 216 (Declaration of Intervention by El Salvador, Order of 4 October). For critical comments on this decision, see, e.g., Greig, supra note 28, at 310-318; J. Sztucki, Intervention under Article 63 of the ICJ Statute in the Phase of Preliminary Proceedings: The Salvadoran Incident, 79 Aм. J. INT'L L.(1985) 1005.

30 S. Bernárdez, L'Intervention dans la Procédure de la Cour Internationale de Justice, 256 ReCUEIL DES CoURS 306 (1995): “La contestation entre les parties qu'envisage l'article doit concerner «l'interprétation d'une convention». Il faut qu'il y ait désaccord entre les parties au différend sur l'interprétation d'un tel instrument, soit que cette interprétation constitue le seul objet du différend, soit qu'elle en représente l'un des éléments." For a different view, see Gaja, supra note 25, at 667.

31 Greig, supra note 28, at 309. See also supra note 9, at 1584. [Emphasis added] 


\section{Interests to Be Protected}

\section{A. Interests in the Construction of a Convention}

While Articles 62 and 63 of the ICJ Statute apply to distinct forms of intervention, there is no indication that the two regulations are mutually exclusive. In the Nuclear Tests (Request for Examination) case, the Solomon Islands, the Federated States of Micronesia, the Marshall Islands and the Samoa Islands sought to intervene under Articles 62 and 63 simultaneously. ${ }^{32}$ Professor Chinkin has foreseen this by saying that: "Circumstances can be envisaged where the construction of a convention is in issue, and a party to a convention considers that it also has a relevant interest which falls outside of the terms of the convention." ${ }^{33}$ Similar situations can also be envisaged where the construction of a provision in a convention is in question and a State party to the convention has a relevant interest which falls within the terms of the provision in it [Emphasis added]. In the latter, a State trying to intervene would have three options: (1) to submit an application for permission to intervene under Article 62; or (2) to make a declaration of intervention under Article 63; or (3) both.

In order to submit an application to intervene in a case before the Court without a declaration of intervention, a State must prove that it has an interest of a legal nature as required under Article 62. ICJ has defined the interest required by Article 62 as "the object of a real and concrete claim of that State, based on law, as opposed to a claim of purely political, economic or strategic nature. ${ }^{34}$ First, the interest required by Article 62 must be based on law, which means, as L'Institut de Droit International has declared, ${ }^{35}$ that rights or obligations of the would-be intervener under public international law can be affected by the decision. Second, the legal interest must be

32 See Request for an Examination of the Situation in accordance with Paragraph 63 of the Court's Judgment of 20 December 1974 in the Nuclear Tests case, Nuclear Test (N.Z. v. Fr.), 1995 I.C.J. 306 (Order of 22 Sept.). The Court dismissed all these requests and declarations when it found the main case inadmissible, emphasizing the incidental nature of intervention. Id.

33 Chinkin, supra note 8, at 154.

34 See Territorial and Maritime Dispute (Nicar. v. Colom.), 2011 I.C.J. 434 (May 4) (Judgment on the Application by Honduras for Permission to Intervene), available at http:/www.icj-cij.org/docket/files/124/16500.pdf (last visited on Oct. 20, 2013). The Court made the same distinction in the judgment on the application to intervene by Costa Rica. See Territorial and Maritime Dispute (Nicar. v. Colom.), 2011 I.C.J. 358 (May 4) (Judgment on the Application by Costa Rica for Permission to Intervene), available at http://www.icj-cij.org/docket/files/124/16482.pdf (last visited on Oct. 20, 2013). See also supra note 22, at 745.

35 L'Institut de Droit International, Judicial and Arbitral Settlement of International Disputes Involving More than Two States (1999) art. III (10), available at http://www.idi-iil.org/idiE/resolutionsE/1999_ber_02_en.PDF (last visited on Oct. 16, 2013). 
real and concrete as opposed to general interest which can be regarded as too remote from the specific situation at issue in the main proceedings.36 It will not be sufficient for a would-be intervener based solely on Article 62 to show merely that it is a party to the convention to be construed by the Court in the case.

In the Sovereignty over Pulau Ligitan and Pulau Sipadan case, ICJ has admitted that some of the treaties which the Philippines invoked may have shown a certain interest in legal considerations before the Court. ${ }^{37}$ In these instruments, however, the Philippines has not shown any legal interest that might be affected by the Court's interpretation in the main proceedings, because either they form no part of the arguments of Indonesia and Malaysia, or their respective reliance on them does not bear on the issue of retention of sovereignty by the Sultanate of Sulu as described by the Philippines in respect of its claim in North Borneo. ${ }^{38}$ In the Court's view, the interest shown by the Philippines would not be affected by the Court's interpretation in the main proceedings. Consequently, the Philippines has failed to discharge its burden of proving an interest of a legal nature in the meaning of Article 62 of the ICJ Statute. ${ }^{39}$

The Philippine Application being rejected, it would be still possible for a third State party to a multilateral treaty to have a legal interest in the Court's interpretation of the treaty in the case. While accepting the compulsory jurisdiction of the Court by declaration, some States would have noticed that such a situation could happen. In the Declaration of 1946 accepting the Court's jurisdiction, the US excluded "disputes arising under a multilateral treaty, unless all parties to the treaty affected by the decision are also parties to the case before the Court." ${ }^{40}$ Some States including the Philippines have adopted similar formulations in their declarations. ${ }^{41}$

This possibility can be also illustrated by reference to the Certain Phosphate Lands in Nauru case. Nauru's claims were based on the Trusteeship Agreement to

36 Supra note 15 , at 742.

37 Supra note 2, at 603.

38 Id.

39 Id. Judge Oda has expressed the view that if a request for permission to intervene as a non-party is to be rejected, the burden should be placed on the parties to the principal case to show that the interest of the third State will not be affected by the decision in the case. See Sovereignty over Pulau Ligitan and Pulau Sipadan (Indon. v. Malay.), Judgment, 2001 I.C.J. 618 (Oct. 23) (Dissenting Opinion of Judge Oda), available at http://www.icj-cij.org/docket/ files/102/7702.pdf; Whaling in the Antarctic (Austl. v. Japan), 2013 I.C.J. (Feb. 6) (Separate Opinion of Judge Cançado Trindade), available at http://www.icj-cij.org/docket/files/148/17272.pdf (all last visited on Oct. 18, 2013).

40 This exclusion clause is known as the Vandenberg reservation. For the Declaration made by the United States, see S. Rosenne, Documents on the International Court of Justice 782-783 (1991).

41 The Vandenberg reservation was quoted and discussed in: Military and Paramilitary Activities in and against Nicaragua (Nicar. v. U.S.), Judgment, 1986 I.C.J. 31-38 (Jun. 27). For similar declarations, see, e.g., those made by El Salvador, India, Malta, Pakistan, and the Philippines in Rosenne, supra note 40, at 641, 693, 711, 733 \& 738 (1991). 
which the United Kingdom and New Zealand were also parties. Nauru alleged that Australia breached its obligations arising from the Agreement under which Australia, New Zealand and the United Kingdom constituted the Administering Authority with respect to Nauru. ${ }^{42}$ As the three States were joint trustees of the territory, Nauru's allegations against Australia were equally applicable to the United Kingdom and New Zealand. The obligations of the joint trustees owed to the beneficiary under the Agreement might be joint as contended by Australia or joint and several as contended by Nauru. ${ }^{43}$ In either way, a finding by the Court regarding the existence and the content of the responsibility attributed to Australia by Nauru might well have implications for the legal situation of the other two States concerned. $^{44}$

As the Trusteeship Agreement was no longer in force, Article 63 of the ICJ Statute could not be applied to that case. If the Agreement had been still in force and the interpretation of the Agreement had been contested at the merits phase, however, the United Kingdom and New Zealand could have intervened in the proceedings under Article 63, and arguably under Article 62 as well, under the condition that other requirements for intervention had been met. One of these requirements expressly stipulated in Article 62 is the possibility of the interest being affected by the decision in the case.

\section{B. Possibility of Being Affected by the Court's Decision}

A State seeking to intervene under Article 62 must request permission based on an interest of a legal nature "which may be affected by the decision in the case." It does not mean that the legal interest will be affected or must be affected. ${ }^{45}$ It is enough to show that the legal interest may be affected by the decision of the Court in the case. Even in this case, however, the third State should prove "in what way" the interest may be affected. ${ }^{46}$ Further, the 'decision' within the meaning of Article 62 is not limited to the dispositif, that is, the operative part of the judgment. It may also include, as stated in the Sovereignty over Pulau Ligitan and Pulau Sipadan

42 See Certain Phosphate Lands in Nauru (Nauru v. Austl.), Judgment, 1992 I.C.J. 261 (Jun. 26).

43 Id. at 258. See also Certain Phosphate Lands in Nauru (Nauru v. Austl.), Judgment, 1992 I.C.J. 283-286 (Jun. 26) (Separate Opinion of Judge Shahabuddeen), available at http://www.icj-cij.org/docket/files/80/6799.pdf (last visited on Oct. 18, 2013).

44 Id.

45 Land, Island and Maritime Frontier Dispute (El Sal. v. Hond.), Judgment, 1990 I.C.J. 117 (Sept. 13). [Emphasis added]

46 Supra note 34.[Emphasis added] 
case $^{47}$ the reasoning which constitute the necessary steps to the dispositif. Professor Bonafé has asserted: "It would not be asked to predict the decision of the Court on the merits, but it will have to take into account all the possible outcomes of the decision and demonstrate that there is at least a chance that the final decision in the main proceedings will affect its legal interests in order to be granted permission to intervene." $^{48}$

It is conceivable that a third State has a legal interest which would not only be affected by a decision but also form the very subject-matter of the decision. In such a case, the Court would not be able to continue the proceedings in the absence of the third State's consent to its jurisdiction. In the Monetary Gold Removed from Rome in 1943 case, ICJ declined its jurisdiction for that reason. ${ }^{49}$ In the Land, Island and Maritime Frontier Dispute case, ${ }^{50}$ the Chamber has stated that if the legal interests of a third State would form part of the very subject-matter of the decision, this would doubtless justify an intervention by the third State under Article 62. In such a case, the Court will be able to decide the dispute only when the third State intervenes as a party. ${ }^{51}$ If a third State seeks to intervene as a party, a jurisdictional link between it and either or both of the parties would be necessary. ${ }^{52}$

By contrast, if the legal interests of a third State may be affected by the decision but does not form the very subject-matter of the decision, the third State may submit a request for permission to intervene as a non-party. In the Land, Island and Maritime Frontier Dispute case, the Chamber has determined that the existence of a valid link of jurisdiction between such a State and the parties is not required for intervention as a non-party. ${ }^{53}$

49 Monetary Gold Removed from Rome in 1943 (It. v. Fr., U.K. \& U.S.), Judgment, 1954 I.C.J. 32 (Jun. 15). See also East Timor (Port. v. Austl.), Judgment, 1995 I.C.J. 102 (Jun. 30).

50 Supra note 45 , at 116.

51 Supra note 15 , at 744 .

52 Land, Island and Maritime Frontier Dispute (El Sal. v. Hond.), Judgment, 1992 I.C.J. 610 (Sept. 13), available at http:// www.icj-cij.org/docket/files/75/6657.pdf (last visited on Oct. 28, 2013). See also supra note 34, at 432 ๆ 28. For a detailed account of jurisdictional link, see, e.g., supra note 9, at 1558-1562. A third State considering itself to be an 'indispensable party' would have three options: to intervene as a party provided that the requirements for joinder of parties were met, not to intervene, or possibly to intervene as a non-party claiming that the case should be dismissed. See H. S. Park, 'Essential Parties' and Intervention before ICJ '필수적 당사국'의 소송참가 (available only in Korean), 47 KOREAN J. INT'L L. 156-158 (2002).

53 Supra note 45, at 135. Article 81, paragraph 2 of the Rules of Court requires that an application for permission to intervene set out "any basis of jurisdiction which is claimed to exist as between the State applying to intervene and the parties to the case." According to the Chamber, the use of the word 'any basis'... shows that a valid link of jurisdiction is not treated as a sine qua non for intervention as a non-party. See Land, Island and Maritime Frontier Dispute (El Sal. $v$. Hond.), Judgment, 1990 I.C.J. 135 (Sept. 13). 
Another case may also arise where a treaty allocates rights to the litigating States and a third State seeking to intervene and the rights in issue before the Court are claimable by the third State. ${ }^{54}$ Professor Greig has noted ${ }^{55}$ this substantial link between the third State and the matters in dispute could justify its joinder as a party before the Court. The Certain Phosphate Lands in Nauru case can be taken as an example. If the merits phase continued in that case, each of the two other States concerned could have intervened either as a non-party or as a party ${ }^{56}$ (probably as a co-defendant with Australia). It could have been permitted to intervene as a party if other requirements for joinder of parties, including link of jurisdiction, had been met. $^{57}$

In their declarations accepting the compulsory jurisdiction of ICJ under Article 36, paragraph 2, of its Statute, both the United Kingdom and New Zealand have excluded, inter alia, "disputes in respect of which any other party to the dispute has accepted the compulsory jurisdiction of the International Court of Justice only in relation to or for the purpose of the dispute." ${ }^{58}$ Although obscure, it could arguably protect the two States in view of the following considerations. First, there was no dispute between Nauru on the one hand and the United Kingdom or New Zealand on the other that Nauru might wish to bring to the Court. Second, Nauru accepted the compulsory jurisdiction of the Court on January 29, 1988, and only sixteen months have passed until it submitted its application instituting proceedings against Australia on May 19, 1989. This limitation may have led Nauru to renounce instituting similar proceedings against the United Kingdom and New Zealand. ${ }^{59}$

Articles 63 as well as 62 being silent on the status of an intervening State as a party or as a non-party and the question of jurisdictional link, the same considerations discussed above would be applicable. In the Whaling in the Antarctic case, New Zealand intervenes under Article 63 as a non-party without indicating any jurisdictional link between itself and the parties to the case. ${ }^{60}$

54 Greig, supra note 28, at 330.

55 Id.

56 E.g., In the Territorial and Maritime Dispute case, Honduras primarily requested intervention as a party and, in the alternative, as a non-party. ICJ rejected both of Honduras' requests. See supra note 34, at 426-27, 444 ฯ 12 \& 75.

57 Greig, supra note 28, at 330.

58 See New Zealand declaration of Sept. 22, 1977, in Rosenne, supra note 40, at 724-725. The United Kingdom declaration of January 1, 1969 contains an identical exception and contains another which excludes "disputes with the governments of any other country which is a Member of the Commonwealth with regard to situations or facts existing before $1^{\text {st }}$ of January, 1969." Id. at 780-81.

59 Greig, supra note 28, at 330-331.

60 Whaling in the Antarctic (Austl. v. Japan), Order, 2013 I.C.J. (Feb. 6) 9ף 2-3, 19, available at http://www.icj-cij.org/ docket/files/148/17268.pdf (last visited on Oct. 28, 2013) 
By invoking its right to intervene under Article 63, New Zealand should only show that the construction of the International Convention for the Regulation of Whaling to which it is a party is in question in the case. As seemingly argued by Japan, ${ }^{61}$ however, New Zealand had legal interests which might be affected by the construction given to the Convention in the reasoning, or the operative part, of the judgment in the case. The Court's interpretation will be equally binding upon the intervening State in accordance with Article 63, paragraph 2 of the ICJ Statute. ${ }^{62}$ There is no such comparable provision in Article 62, however. In this light, a question may remain about what legal effect the Court's judgment has upon an intervening State.

\section{Effects of Judgments on Intervening States}

\section{A. Effects on a Party Intervener}

If a State intervenes as a party either under Articles 62 or 63, the decision of the Court in the case will be binding upon the intervening State in accordance with Article 59 of the ICJ Statute. Article 59 provides that: "The decision of the Court has no binding force except between the parties and in respect of that particular case." Thus, the decision is in principle res inter alios acta (a matter which, in law, exclusively concerns others) for States other than the parties to the case.

While the term 'decision' used in Article 59 mainly concerns judgments on the merits, it also covers other decisions such as judgments on preliminary objections and orders indicating provisional measures. No decision should be excluded from the ambit of Article 59 if the content can be bound..$^{63}$ In principle, only the operative part of judgment or other decision has binding force. In the Polish Postal Service in

61 See, Written Observation of Japan, supra note 1, at 9ף 1-4.

62 This was confirmed by New Zealand. See Whaling in the Antarctic (Austl. v. Japan), Order, 2013 I.C.J. (Feb. 6), supra note 60, at 9 2-3. For an argument that a State intervening under Article 63 is bound by the judgment 'equally' with the parties only 'in respect of that particular case,' see supra note 9, at 1596. For an argument that the parties may also be bound to observe the Court's interpretation of the law in future cases, see C. Brown, Article 59, in The STATUTE OF THE INTERNATIONAL COURT OF JUSTICE: A COMMENTARY 1437-1438 (2012).

63 For the binding force of judgments on preliminary objections, see, e.g., Application of the Convention on the Prevention and Punishment of the Crime of Genocide (Bosn. \& Herz. v. Serb. \& Montenegro), Judgment, 2007 I.C.J. 101 (Feb. 26), available at http://www.icj-cij.org/docket/files/91/7349.pdf. For the binding force of orders indicating provisional measures, see, e.g., LaGrand (Ger. v. U.S.), Judgment, 2001 I.C.J. $502-503$ (Jun. 27), available at http:// www.icj-cij.org/docket/files/104/7736.pdf (all last visited on Oct. 25, 2013). See also Brown, supra note 62, at 14291430. 
Danzig case, ${ }^{64} \mathrm{PCIJ}$ has stated: "It is certain that the reasons contained in a decision, at least in so far as they go beyond the scope of the operative part, have no binding force as between the Parties concerned." Similarly, ICJ has observed in the Bosnian Genocide case as follows:

....in respect of a particular judgment it may be necessary to distinguish between, first, the issues which have been decided with the force of res judicata, or which are necessarily entailed in the decision of those issues; secondly any peripheral or subsidiary matters, or obiter dicta; and finally matters which have not been ruled upon at all. ${ }^{65}$

The term 'binding force' laid down in Article 59 should be distinguished from the force of res judicata. For judgments of ICJ, the force of res judicata results from the combined effect of Articles 59, 60 and $61 .{ }^{66}$ In the Bosnian Genocide case, ICJ has explained:

The principle [of res judicata pro veritate habetur] signifies that the decision of the Court are not only binding on the parties, but are final, in the sense that they cannot be reopened by the parties as regards the issues that have been determined, save by procedures, of an exceptional nature, specially laid down for that purpose. Article 59 of the Statute, notwithstanding its negative wording, has at its core the positive statement that the parties are bound by the decision of the Court in respect of the particular case. Article 60 of the Statute provides that the judgment is final and without appeal; Article 61 places close limits of time and substance on the ability of the parties to seek the revision of the judgment. ${ }^{67}$

The Chamber in the Land, Island and Maritime Frontier Dispute case also declared that "the force of res judicata does not operate in one direction only: if an intervener becomes a party and is thus bound by the judgment, it becomes entitled equally to assert the binding force of the judgment against the other parties." 68

On the other hand, the ICJ orders indicating provisional measures under Article 41 of its Statute would not have the force of res judicata, ${ }^{69}$ though they are binding. Under Article 76, paragraph 1, of the Rules of Court, ICJ may, at the request of a party, revoke or modify any decision concerning provisional measures at any time

\footnotetext{
64 Polish Postal Service in Danzig, 1925 P.C.I.J. (ser. B), No. 11, at 29-30 (Advisory Opinion).

65 See Application of the Convention on the Prevention and Punishment of the Crime of Genocide, supra note 63, at 95.

66 Rosenne, supra note 8, at 1598. See also Brown, supra note 62, at 1428.

67 Application of the Convention on the Prevention and Punishment of the Crime of Genocide, supra note 63, at 90.

68 Supra note 52, at 610.

69 Brown, supra note 62, at 1430-1431.
} 
before the final judgment in the case if, in its opinion, some change in the situation justifies such revocation or modification. Under Article 76, paragraph 3 of the Rules, moreover, the rejection of a request for the indication of provisional measures does not prevent the party who made it from making a fresh request in the same case based on new facts.

\section{B. Effects on a Non-Party Intervener}

When the construction of a convention to which the intervener is also a party is in question, the construction given by the Court's judgment will be equally binding upon the intervening State under Article 63. In the case of intervention under Article 62 of the ICJ Statute, however, the position does not seem clear. Article 62 admits that the legal interest of an intervening State may be affected by the decision of the Court in the case, while Article 59 stipulates that the decision of the Court has no binding force except between the parties and in respect of that particular case. Thus, if a third State intervenes as a non-party, it has been a matter of doubts whether the decision of the Court in the case will also be binding upon the non-party intervener. ${ }^{70}$ In the Land, Island Maritime Frontier Dispute case, the ICJ Chamber has declared:

It appears appropriate for the Chamber to make some observations on the effect of the present Judgment for the intervening State. The terms on which intervention was granted, as stated in paragraph 102 of the 1990 Judgment, were that Nicaragua would not, as intervening State, become party to the proceedings. The binding force of the present Judgment for the parties, as contemplated by Article 59 of the Statute of the Court, does not therefore extend also to Nicaragua as intervener.

The Chamber considers it correct that a State permitted to intervene under Article 62 of the Statute, but does not acquire the status of a party is not bound by the Judgment given in the proceedings in which it has intervened. ${ }^{71}$

This approach is, however, open to some criticism. The effect of this approach arguably devaluates the right of the intervening State to participate in the proceedings without any consequential duties. ${ }^{72}$ Intervention is not a procedure whereby the Court can obtain further information about the issues raised by the case 
from non-parties to the proceedings. ${ }^{73}$ Nor is it a procedure on the receipt of amicus curiae briefs. It is the procedure for a third State having relevance to protect its legal interests from being affected by the decision in the main proceedings. If Article 59 is regarded as providing adequate protection for third States, Article 62 would be redundant. $^{74}$

The Chamber has stated that: "a State which considers that its legal interest may be affected by a decision in a case has the choice, to intervene or not to intervene; and if it does not, proceedings may continue, and that State is protected by Article 59 of the Statute." 75 This statement may imply that a third State, by becoming an intervener, ceases to be protected by Article 59. It is true that the Chamber has admitted the possibility of a third State intervening as a party to a case and thus being bound by the decision in the case. However, the Chamber has not given convincing reasons why a non-party intervener under Article 62 is not bound by the judgment in the proceedings in which it has intervened. The reason has been just stated in $1990:^{76}$

The intervening State does not become a party to the proceedings, and does not acquire the rights, or become subject to obligations, which attach to the status of a party, under the Statute and Rules of Court, or the general principles of law.

After citing this observation, the Chamber added in 1992 that: "In these circumstances, the right to be heard, which the intervener does acquire, does not carry with it the obligation of being bound by the decision." ${ }^{77}$ Although a non-party intervener would not be bound by the decision within the meaning of Article 59 of the Statute, it might still be bound by the judgment on other grounds. [Emphasis added] It may be recalled in this respect that a non-party intervener under Article 63, such as New Zealand in the Whaling in the Antarctic case, would be bound by the interpretation of the treaty in the judgment.

\footnotetext{
73 Supra note 45, at 130. For the procedure on the receipt of information relevant to a case brought before the Court, see I.C.J. Statute art. 34. It reads:

1. [......]

2. The Court, subject to and in conformity with its Rules, may request of public international organizations information relevant to cases before it, and shall receive such information presented by such organizations on their own initiative.

3. Whenever the construction of the constituent instrument of a public international organization or of an international convention adopted thereunder is in question in a case before the Court, the Registrar shall notify the public international organization concerned and shall communicate to it copies of all the written proceedings.

74 Supra note 9, at 1566.

75 Supra note 45, at 115. See also Continental Shelf, supra note 10, at 26.

76 Supra note 45, at 135-36.

77 Supra note 52, at 609-610.
} 
The observations of the Chamber would be more doubtful if a third State may have the choice to intervene under Article 62 or Article 63. When the construction of a convention is in question in a case and simultaneously a third State party to the convention has legal interests which may be affected by the construction in the Court's judgment, the State may arguably intervene as a non-party either under Article 62 or Article 63. ${ }^{78}$ Under Article 62, according to the Chamber, such a nonparty intervener would not be bound by the judgment. Under Article 63, however, it would be bound at least to a limited extent. Professor Greig has pointed out that there would be no logic in such a distinction. ${ }^{79}$

A third State can intervene as a non-party under Article 62 only if its legal interest may be affected by the decision in the case. The legal interest of a non-party intervener under Article 62 might be affected by the decision in the case only if the decision could have some legal effect on the intervener. Although the Chamber has declared that the judgment on the merits is not res judicata for a non-party intervener, ${ }^{80}$ it does not amount to say that the judgment could have no legal effect on such an intervener. Therefore, a more reasonable interpretation of Article 62 taken together with Article 63 would be that a non-party intervener should be bound, at least to a limited extent, by the decision in the proceedings in which it intervened. ${ }^{81}$ Indeed, Professor Chinkin asserts that, by analogy with Article 63, a non-party intervening State must be bound by the judgment to the extent that it relates to the intervention. ${ }^{82}$ To the same effect, L'Institut de Droit International adopted a resolution in 1999 at the Berlin Session, which declared as follows:

The decision of the court or tribunal is binding on the intervening State to the extent of the admitted intervention. To the same extent, the decision is binding on the principal parties in their relations with the intervening State. ${ }^{83}$

Although the ICJ judgment is binding on a non-party intervener under Article 62,

78 See pt. III above.

79 Greig, supra note 28, at 332.

80 Supra note 52 , at 610.

81 In that regard, Greece, having intervened under Article 62 in the Jurisdictional Immunities case, could not in principle claim against Italy any more that the latter State should deny the jurisdictional immunities of Germany in the enforcement of the Distomo decision rendered by Greek court. For the ICJ's judgment, see Jurisdictional Immunities of the State (F.R.G. v. Italy: Greece Intervening), Merits, Judgment of 3 February, available at http://www.icj-cij.org/ docket/files/143/16883.pdf(last visited on Oct. 20, 2013).

82 Supra note 9, at 1564.

83 L'Institut de Droit International, Judicial and Arbitral Settlement of Disputes Involving more than Two States, 68 ANNUAIRE DE IDI 377 (1999), re-cited from Brown, supra note 62, at 1440. 
it is something other than res judicata, as is the case of orders indicating provisional measures for the principal parties. First, the term 'decision' used in Article 62 is broader in scope than that used in Article 59, since the former includes not only the operative part of judgment but also the reasons constituting the necessary steps to it. The reasons included in the judgment do not in principle have the force of res judicata. ${ }^{84}$ Second, a situation can be envisaged where a third State intervenes under Article 62 as a non-party to protect its rights which impose corresponding obligations upon one of the original parties to the case but the party admits in the proceedings an allegation to the detriment of the non-party intervener's rights. If those rights were consequently affected by the decision of the Court, that decision would not prevent the non-party intervener from submitting to the Court an application instituting fresh proceedings against the original party.

\section{Conclusion}

When the interpretation of a multilateral treaty is in question in a case before ICJ, a third State party to the treaty has the right to intervene under Article 63 of the ICJ Statute. It is conceivable that such a third State has also a legal interest which may be affected by the interpretation of the treaty given in the judgment in the case and accordingly may submit a request for permission to intervene under Article 62. Such a third State can invoke one of the two provisions alone or both of them simultaneously.

In accordance with Article 63, paragraph 2 of the ICJ Statute, an intervener even as a non-party to the case would also be bound, at least to a limited extent, by the decision in the proceedings. For an intervener as a party to the case, the operative part of the judgment will have the force of res judicata by the combined effect of Articles 59, 60 and 61. For a non-party intervener, the decision under Article 62 would not have such force. However, it would bind upon the intervener to the extent where admitted.

In so far as an intervening State is bound by the Court's judgment, there would be no significant difference between the two types of intervention under the ICJ Statute. If a State may intervene under both Articles, it would choose between Articles 62 and 63 according to the relative burden of proof and the relative scope of 
the legal interest on the one hand and the terms of the convention on the other. For such a would-be intervener, the choice will mainly depend on whether and to what extent the terms of the provision in the convention covers, or is covered by, the legal interest which it seeks to protect. 